\title{
CONSTITUTIONAL FOUNDATIONS FOR THE COORDINATION OF RECEIPTED AND NATIONAL LITHUANIAN LAW IN 1918-1920
}

\author{
Jevgenij Machovenko, \\ Professor at the Department of Public Law \\ of Vilnius University, \\ Doctor of Social Sciences (HP), Full professor \\ orcid.org/0000-0003-2930-3526 \\ jevgenij.machovenko@tf.vu.lt
}

Dovile Valanciene,

Assistant at the Department of Public Law

of Vilnius University,

Doctor of Social Sciences, Associate Professor

orcid.org/0000-0002-1034-1074

dovile.valanciene@tf.vu.lt

\section{Summary}

The research object of this study is the provisions of the Provisional Constitutions of 1918, 1919 and 1920 concerning the establishment of the Lithuanian legal system. The aim of the study was to determine what was the basis for the reception of foreign law and the particularism of the law, what law was recepted and what was the relationship between it and the newly created national law. The main methods used are systematic, teleological, historical, linguistic, and comparative. This article presents an original vision of recepted law and a critical assessment of the interwar Lithuanian governmental decision to completely eliminate recepted law. In the authors' opinion, law reception and particularism enshrined in the Provisional Constitutions met the expectations of the citizens, and the government's ambition to completely eliminate recepted law in all areas of people's activities in the intensive development of the national law was in line with the strategic interests of the state and society. Particularism was a natural expression of pluralism inherent in the Western legal tradition and had a great potential for the development of Lithuanian law, which was not exploited due to the negative appreciation of particularism and the attempt to eliminate it completely.

Acts issued by the Russian authorities in 1914-1915 and by the German authorities in 1915-1918 restricted the rights of Lithuanian residents, severely restricted monetary and property relations, made it difficult to rebuild the country's economy, providing for repressive or restrictive measures against the citizens of hostile states. The restored state of Lithuania endeavoured to establish peaceful relations with all states, including those with whom Russia and Germany were at war. Cancelling the law imposed by the Russian and German authorities during the war was a reasonable and useful decision of the Lithuanian State authorities.

The interpretation of the constitutional provision "[laws] which existed before the war» as "which existed before August 1,1914», common in the historical legal literature of Lithuania, is incorrect. The question what laws were recepted has to be addressed not by the date of the adoption o a certain act, but by its content - insofar it is linked or unrelated to the First World War. All acts by which the Russian Empire intervened or were preparing to intervene in this war shall be considered to be excluded from the legal system of the 
restored State of Lithuania in the sense of the constitutional norm "[laws] which existed before the war» and the general spirit of this Constitution.

The system of constitutional control entrenched in the Provisional Constitutions, where a court or an executive authority verified the compliance of a recepted law with the Constitution before applying it is subject to criticism from the standpoint of contemporary legal science, but under the conditions of Lithuania of 1918-1920, it was flexible, fast, allowing citizens to raise the issue of the constitutionality of the law and present their arguments.

Key words: Legal history; Lithuanian Provisional Constitutions; law reception; particularism of law; Western legal tradition; legal pluralism; public law; private law

\section{Introduction}

In 2020, the Lithuanian people celebrate the centenary of the convocation of the Constituent Seimas of the Republic of Lithuania, which resolution of May 15 completed the reconstruction of the State. The years 1918-1920 were a period of intense legal work. Its main results are the Lithuanian legal system, based on three Provisional Constitutions, which merged newly adopted national and recepted foreign law. The preamble to the valid Constitution of the Republic of Lithuania (1992) contains a reference to the Statutes and Constitutions of the Republic of Lithuania (interwar and 1990) as the foundations of a multi-year Lithuanian statehood. However, the three Provisional Constitutions receive very little attention in historical legal literature as being shortlived, unable to make a more tangible impact on our constitutional traditions (Maksimaitis, 2002). Although significant monographs (Grisxkevicx, et al., 2016, Maksimaitis, 2005; Maksimaitis, 2011) and articles (Machovenko, 2017; Machovenko, 2018; Machovenko, Valanciene, 2018; Machovenko, 2019) have appeared, examining various Lithuanian institutes of constitutional law of 1918-1920, there are still gaps there. In addition, even recent publications tend to demonstrate stereotypical views on the insignificance of the Provisional Constitutions as the subject of research. For example, the dissertation of A. Juskeviciute-Viliene concludes that the Provisional Constitution of 1918 had almost no significance in restoring the Lithuanian economy and regulating economic life (Jusxkevicxiuxtex-Vilienex, 2017).

This article presents an original vision of recepted law and a critical assessment of the interwar Lithuanian governmental decision to completely eliminate recepted law. The research object of this study is the provisions of the Provisional Constitutions of 1918, 1919 and 1920 (Fundamental Laws of the Provisional Constitution of the State of Lithuania, 1918; Fundamental Laws of the Provisional Constitution of the State of Lithuania, 1919; Provisional Constitution of the State of Lithuania, 1920) concerning the establishment of the Lithuanian legal system. The aim of the study was to determine what was the basis for the reception of foreign law and the particularism of the law, what law was recepted and what was the relationship between it and the newly created national law. The methodological significance of this study was based on the teaching on the Western legal tradition given in H. J. Berman's monograph (Berman, 1999). The main methods used are systematic, teleological, historical, linguistic, and comparative.

\section{Constitutional Foundations of Foreign Law Reception}

At the time of the adoption of the first of the three Provisional Constitutions, the territory of Lithuania was still occupied by Germany. As the defeat of Germany in the First World War and the end of the occupation were perceived to come soon, it was important to decide on the law that Lithuanian people had to rely on in the future. Since the end of 1917, the political elite relied on the vision that the State of Lithuania was being restored and it was a continuation of the pre-existing statehood. The decision to return to the last laws of the independent Lithuania would have been doctrinally correct. However, such return would have been inconsistent with the needs and expectations of the inhabitants. After all, those last laws were the privileges of the Grand Duchy of Lithuania, resolutions of the 
Seimas, the Statute of Lithuania and other acts adopted in the late 18th century or even earlier, also the old customary law. During the 19th century, fundamental changes in the society, people's consciousness and the economy were taking place, moreover, the legal relations based on the law of the Grand Duchy of Lithuania practically almost disappeared (Maksimaitis, 2001).

The solution was obvious and well-known in history, but it was necessary to make a decision on the preferred option. In 1918, the Provisional Constitution solved this issue in an original and interesting way. Article 24 of this Constitution (as well as Article 28 of the Provisional Constitution of 1919 literally repeating it) established that in the areas of human activities where laws of the Republic of Lithuania are not yet in force, pre-war laws remain in force insofar as they do not conflict with this Constitution.

The aforementioned constitutional provision is described in Lithuanian historical legal literature as follows:

1) the continuity of legal regulation is ensured and the threat of legal vacuum is eliminated;

2) the foreign law that is inappropriate for the Lithuanian society remains in effect, i.e. its reception is going on;

3) the intention of the Government of the Lithuanian State to regulate all relations by national legal norms is explicit;

4) the adoption of a national law means that the corresponding recepted law ceases to have effect;

5) there is a transitional period until all recepted are superseded by new national law;

6) interpreting the provision «before the war» as «before August 1, 1914», the norms adopted by the German occupation authorities and those issued by the Russian authorities after the beginning of the war are included into the Lithuanian legal system;

7) the particularism of law is consolidated - the three pre-war systems of recepted private law that existed before the war remain: a) the one based on Volume 1 of Code X of the Russian Empire in a large part of the territory of Lithuania, b) the one based on the Napoleonic Code - in Lithuanian Uznemune, c) based on Part III of the Compendium of Domestic Laws of the Baltic Governments of the Russian Empire - in a small part of the territory of Lithuania which became part of the Latvian State in 1918, but in 1921 it was recovered by Lithuania under an interstate treaty (Palanga district and parts of Zarasai county). Two criminal law systems also appear: a) the one based on the Criminal Statute of the Russian Empire - in a large part of the territory of Lithuania and b) the one based on the Criminal Code of the German Empire - in the recovered Klaipeda region in 1923 (Maksimaitis, 2001).

While basically agreeing with such evaluations, we would like to make two points:

1) The authors of the text of the Provisional Constitution of 1918 are characterized by maximalism and idealism - the pursuit of complete elimination of recepted law in all areas of people's activities through intensive development of the national law - both in the public and private spheres, and the belief that it is possible and useful. Presumably, the reason for this aspiration was the negative evaluation of recepted law as being essentially inappropriate for Lithuania and recepted compulsively, just because it was meant to avoid chaos and not to leave the relationship without any legal regulation.

This position of the interwar Lithuanian legislator can be understood and justified. To abolish recepted law means to liquidate the order established by the occupying Russian authorities, the consequences of its policy towards Lithuania, and the institutes of law imposed on the Lithuanian nation. In 1918-1920, it was crucial to convince the people of Lithuania that they were an integral nation of Lithuania, that Lithuania was their common state, that all its citizens were equal according to law. Common national law would have been an important contribution to the development of citizenship and the loyalty of the population. The removal of recepted law as soon as possible was a guarantee of state strength and political stability. Today, however, the law reception that took place can be seen as part of the Western legal tradition. In retrospect, recepted law can be viewed as an inheritance, a value, an important resource, the possession of which is an advantage and not a disadvantage.

2) the negative evaluation of particularism was established in both interwar Lithuanian and contemporary historical legal literature as well as the desire to emphasize that particular- 
ism had to be sanctioned «out of trouble when there was no other way out». In one of our earlier publications, we have already drawn the attention of readers to the fact that particularism, especially in private law, is not evil per se (Machovenko, 2017). According to H. J. Berman, particularism is one of the expressions of pluralism in the Western legal tradition, and pluralism itself (the existence of cooperative and competing legal systems and jurisdictions) is a key identifying feature and a driving force of this tradition (Berman, 1999). The Western legal tradition is characterized by the need and ability to constantly evolve, grow quantitatively and qualitatively. In most cases, this growth is evolutionary and has enough internal resources of the Western legal tradition. Sometimes, however, this tradition faces such challenges and experiences such a crisis that needs to be resolved promptly and in the short term. A «legal revolution» is underway (according to H. J. Berman's terminology) - rapid transformation of the Western legal tradition, its qualitative leap (Berman, 1999). Such a revolutionary transformation of the legal system may not have enough its own internal resources and will have to borrow from other legal systems. Law reception is such borrowing. Recognized law is integrated into the legal system and becomes part of it which is alien only in terms of its origin.

The existence of different legal sub-systems in Lithuania meant that the legal regulation took the utmost account of the specific nature of public relations historically established in a particular territory. In addition, the coexistence of general and local laws of the Russian Empire, French and German law within the Lithuanian legal system meant that in certain cases citizens had the opportunity to choose jurisdiction and to find a better regulation. For example, civil metric existed only in Klaipeda region, therefore, non-denominational persons or those wishing to use ecclesiastical registration could register marriage in Klaipeda. This particularism of law also meant that there was abundant and very rich material for comparative legal analysis. Such a hypothetical analysis could identify the advantages of different legal subsystems, combine them and ensure a qualitative leap in the Lithuanian legal system, its "legal revolution». Unfortunately, this potential was not exploited in interwar Lithuania. Little progress was made in systemizing, especially in codifying Lithuanian law. Commissions for the development of civil and criminal codes were organized before 1940. Before the occupation of Lithuania by the Soviet Union it was possible to draft only a few sections. The most often cited reasons were the lack of human and material resources, a very disadvantaged unstable political situation for the development of law, a coup d'état of 1926, after which Lithuania de facto lost its parliament (The Seimas, dissolved in 1927, no longer convened, and in 1936, the elected Seimas was only a para-parliament since it passed only bills, not laws). In our opinion, one of the most important reasons was the goal of creating completely original national codes - an idealistic and volatile governmental solution. Though the Provisional Constitutions of 1918 and 1919were in force for a very short time, their pursuit to get rid of the recepted law and rely only on the new national law dominated in the elite consciousness and was realized until the occupation of Lithuania in 1940.

\section{What was the pre-war law in Lithuania?}

The specifications of Provisional Constitutions on the validity of pre-war law in Lithuania received little attention from researchers. The issue of why the legal norms adopted by the Russian authorities from the beginning of the war until the German occupation of the territory of Lithuania was not thoroughly investigated in the historical legal literature. These norms actually existed in Lithuania and their reception would have been a logical step. It is not difficult to see that most of these norms were linked to the prohibition or restriction, of certain activities, expropriation of property and introduction of new obligations. For example, the citizens of hostile states were forbidden to acquire and dispose of real estate in the Russian Empire by the Emperor's Order of October 5, 1914 (Averbah, 1915). At the beginning of the First World War, the nation of Lithuania had not yet restored its statehood, the decision of the Russian authorities to participate in the war was not an expression of the will of the Lithuanian people, legal acts related to military actions were not issued by the Lithuanian state institutions. To recept these le- 
gal norms meant taking some responsibility for decisions that were not in the best interests of the Lithuanian nation. Reconstructed State of Lithuania endeavoured to establish peaceful relations with all states, including those with whom the Russian Empire was at war. Reception of the legislation providing for repressive or restrictive measures against the citizens of those states would have deviated from the principles and obligations of foreign policy declared by the State of Lithuania. The very aspiration to base the activities of the State of Lithuania and its citizens only on those norms which, in our opinion, were of great political and legal significance at the time of peace, was a clear signal to the neighbouring nations. Presumably, for the same reasons, the legal regulations introduced by the German occupation authorities, which were in force between 1915 and 1918, were not preserved.

Governmental acts of both public and private law of Russian authorities in 1914-1915 and German authorities in 1915-1918 constrained and restricted the rights of the Lithuanian population. The government of the restored state of Lithuania tried not only to consolidate the catalogue of civil liberties and rights in the Provisional Constitutions, but also to create conditions for their actual implementation. For example, as early as 1919, the Law on Press and the Law on Societies, both being important to the development of democracy, were adopted (political parties were established on the basis of the latter), the Law on Meetings was adopted in 1920. Legislation of Russian and German authorities adopted during the war severely restricted monetary and property relations, made it difficult to rebuild the economy of the country. Eliminating laws that restrict both political rights and economic freedom was certainly a reasonable and useful solution. There were, of course, some legal acts of Russian and German authorities that could be called neutral (for example, on the legal status of Cossacks, who did not live in Lithuania) or even useful (for example, on the fight against crime). Reception of such norms would have been a feasible and even meaningful step. However, such a selective reception would have been inconsistent from a doctrinal point of view, and would have been very complicated from a practical point of view. Therefore, cancelling all laws imposed by the Russian and German authorities during the war was the simplest and most meaningful solution of all (however, some exceptions were made with respect to German criminal law).

It is customary in Lithuanian historical legal literature to interpret the constitutional provision «[laws] that existed before the war» as "that existed before August 1, 1914». But was this what the authors of the text of the Provisional Constitution meant? Why did they not give that exact date, as it is common practice to set limits on the validity of an act? It is unlikely that in 1918 Lithuanian citizens could remember the date of the war so easily, all the more that it was not a well-known fact. The «Chrestomatous» start of World War I, July 28 (that day the Austro-Hungarian monarchy declared war on the Kingdom of Serbia), was only a later consensus among historians. August 1 as a more relevant date for Russia (when the German Empire de jure declared war on the Russian Empire, which had occupied and annexed Lithuania) is also a date chosen by consensus. By announcing global mobilization on July 31, the Russian government and the Tsar realized that they were de facto launching a war against Germany, and had no doubt that the German government and the Emperor would understand this move accordingly (Suhomlinov, 1924). The mobilization of private cars began on the same day, on July 30 martial law was declared in the Grand Duchy of Finland (an autonomous unit within the Russian Empire), even earlier, on July 29, martial law was declared in the Russian army and navy. If you look at the problem very formally and agree that the "[laws] that existed before the war" are those "that existed before August 1, 1914", then the above mentioned and other acts adopted at the end of July must be considered as recepted and valid in Lithuania in 1918 and later. However, it is clear that these acts, by their content and spirit, are actually acts of war, and their reception and validity would have been contrary to the policy of the restored State of Lithuania, its pursuit of peace and peaceful relations with other states. In our view, it is not the date of adoption of a particular act, but its content is important, insofar as it is linked to or unrelated to World War I. All acts by which the Russian Empire engaged in, or was preparing to engage in, this war are in accordance with 
the meaning of the constitutional norm "[laws] which existed before the war" and the general spirit of this Constitution (the "spirit of the Constitution» is a term widely used by the Constitutional Court of the Republic of Lithuania to interpret the Constitution in force) must be considered as excluded from the legal system of the restored state of Lithuania.

There is an important statement in the constitutional doctrine of the Constitutional Court of the Republic of Lithuania that the Constitution cannot be interpreted on the basis of ordinary laws. However, it would be useful for readers to know that The Provisional Law on the Organization of Courts of 1918 (the first Ordinary Law issued in the restored State of Lithuania, which was in force until 1933) stipulated that courts established at that time must adjudicate civil and criminal cases under the laws «that existed under the Russian rule» (Article 2). Interestingly, the same article refers to Article 24 of the Provisional Constitution, which states «[the laws] which existed before the war». Presumably, the Council of the State of Lithuania, which issued both the Provisional Constitution and the Provisional Law on Judicial Organization, did not see any contradiction here. It is noteworthy that this law also does not contain an exact date, which indirectly confirms our guess that in law reception, not the moment of the adoption of laws but their content was of importance.

Today, such guesses can be confirmed or denied by instituting proceedings in the Constitutional Court, which has the power to formally interpret the Constitution. In the Provisional Constitutions of 1918, 1919 and 1920, the function of constitutional control is not enforced expressis verbis, however, the provision in question is derived from the provision on the validity of recepted laws to the extent that they are not in conflict with the Provisional Constitution. This means that before applying a recepted law, every time it is necessary to determine its compliance with the Constitution. In the absence of any special constitutional control institution, each law enforcement officer had to perform this function on a case-by-case basis. We agree with $\mathrm{M}$. Maksimaitis that not only the courts but also the executive authorities had to decide on the constitutionality of the recepted law (Andriulis, et al., 2002). «Deciding» primarily means «clarify- ing", but no one could prohibit that institution from clarifying the constitutionality issue that has been clarified (of course within the sphere of its competence) to other legal entities (e.g. the court in its decision or the minister of justice in its circular). Such a «fragmented system of constitutional control» enshrined in all three Provisional Constitutions is not common nowadays. It can be reasonably criticized from the standpoint of modern legal science primarily because it cannot ensure a uniform, systematic, comprehensive interpretation of the Constitution, and is not protected from the unprofessional, biased, conjunctural solution of the constitutionality issue. However, under the conditions of Lithuania of 1918-1920, only it could verify the constitutionality of the recepted law. This system also had a number of advantages in that it was flexible, rapid, allowing litigants and interested parties in the executive branch to raise the constitutionality of the law and present their arguments (for comparison, in present-day Lithuania an individual constitutional complaint has been established very recently - citizens can use it to defend their rights from September 1, 2019). Of course, if the obligation of the institutions to review the constitutionality of recepted laws was enshrined at the constitutional level, there should have been a relevant practice as well. We believe that an analysis of practice of executive authorities and law cases would be an interesting and promising line of research. It could be possible to establish who and how many times questioned the constitutionality of the law, how the institution dealt with and how it reasoned its decision. To our knowledge, such studies are not yet available. However, it can already be stated that Provisional Constitutions were richer and the Lithuanian legal system based on them deserves more careful attention from researchers.

\section{Conclusions}

1. Law reception and particularism enshrined in the Provisional Constitutions met the expectations of the citizens, and the government's ambition to completely eliminate recepted law in all areas of people's activities in the intensive development of the national law was in line with the strategic interests of the state and society. Particularism was a natural expression of pluralism inherent in the West- 
ern legal tradition and had a great potential for the development of Lithuanian law, which was not exploited due to the negative appreciation of particularism and the attempt to eliminate it completely.

2. Acts issued by the Russian authorities in 1914-1915 and by the German authorities in 1915-1918 restricted the rights of Lithuanian residents, severely restricted monetary and property relations, made it difficult to rebuild the country's economy, providing for repressive or restrictive measures against the citizens of hostile states. The restored state of Lithuania endeavoured to establish peaceful relations with all states, including those with whom Russia and Germany were at war. Cancelling the law imposed by the Russian and German authorities during the war was a reasonable and useful decision of the Lithuanian State authorities.

3. The interpretation of the constitutional provision "[laws] which existed before the war" as "which existed before August 1, 1914», common in the historical legal literature of Lithuania, is incorrect. The question what laws were recepted has to be addressed not by the date of the adoption o a certain act, but by its content insofar it is linked or unrelated to the First World War. All acts by which the Russian Empire intervened or were preparing to intervene in this war shall be considered to be excluded from the legal system of the restored State of Lithuania in the sense of the constitutional norm "[laws] which existed before the war" and the general spirit of this Constitution.

4. The system of constitutional control entrenched in the Provisional Constitutions, where a court or an executive authority verified the compliance of a recepted law with the Constitution before applying it is subject to criticism from the standpoint of contemporary legal science, but under the conditions of Lithuania of 1918-1920, it was flexible, fast, allowing citizens to raise the issue of the constitutionality of the law and present their arguments.

\section{Bibliography:}

1. Andriulis V., et al. Lietuvos teisès istorija. Vilnius : Justitia, 2002. $542 \mathrm{p}$.

2. Авербах О.И. Законодательные акты, вызванные войной 1914 года с Германией, Австро-Венгрией и Турцией. Вильна : Типография А. Г. Сырпина, 1915. 686 с.
3. Berman H.J. Teisè ir revoliucija. Vakarų teisès tradicijos formavimasis / iš anglų kalbos vertè A. Šliogeris. Vilnius : Pradai, 1999.875 p.

4. Griškevič L., Machovenko J., Paužaitė-Kulvinskienė J., Vaičaitis V.A. Lietuvos konstitucionalizmo istorija (istorinè Lietuvos konstitucija). 1387 m. - 1566 m. - 1791 m. - 1918 m. - 1990 m. : monografija. Vilnius : Vilniaus universiteto leidykla, 2016. 280 p.

5. Juškevičiūtè-Vilienè $A$. Asmens ūkinès veiklos laisvès konstituciniai pagrindai Lietuvoje: ekonominès, istorinès ir lyginamosios jžvalgos : daktaro disertacija, socialiniai mokslai, teisè (01 S). Vilnius : Vilniaus universitetas, 2017.424 p.

6. Lietuvos Valstybės Laikinosios Konstitucijos Pamatiniai Dèsniai. (Valstybès tarybos priimta 1918 m. lapkričio mèn. 2 d.). Lietuvos aidas. 1918-11-13.130(178).

7. Lietuvos Valstybès Laikinosios Konstitucijos Pamatiniai Dèsniai. Lietuvos valstybės tarybos priimti 1919 m. balandžio mèn. 4 d. Priedèlis prie Laikinosios vyriausybès žinių. Nr. 6/24a.

8. Laikinoji Lietuvos Valstybès Konstitucija. Laikinosios Vyriausybès žinios. 1920-06-12. Nr. 37-407.

9. Маховенко Е. Историческая Конституция Литвы как часть западной правовой традиции и место в ней временной Конституции 1919 года. Конституційно-правове будівництво на зламі епох: пошуки оптимальних моделей : матеріали міжнародної науково-практичної конференції (м. Ужгород, 3-4 травня 2019 р.). Ужгород : Ужгородський національний університет, 2019. С. 267-271.

10. Маховенко Е. Конституционные основы литовского частного права 1918-1920 гг. Проблемы гражданского права и процесса : сборник научных статей. Гродно : Гродненский государственный университет им. Янки Купалы, 2017. С. 199-211.

11. Machovenko J. Teisès viešpatavimas 1918 m. ir 1919 m. Lietuvos Valstybès Laikinosios Konstitucijos Pamatiniuose Désniuose. Local administration and Local self-government in the history of law, state and legal thought: Materials of the XXXIX International historical juridical conference (Lviv, November 2-3, 2018). Київ-Херсон : Олді-плюс, 2018. С. 44-54.

12. Machovenko J., Valančienė D. Democracy in Lithuanian Temporary Constitutions of 1918 and 1919. Західні $i$ східні традииіі та впливи в історії права, держави і юридичної думки : матеріали XXXVIII Міжнародної історико-правової конференції (м. Вінниця, 1-3 червня 2018 р.). Київ-Херсон : Олді-плюс, 2018. С. 143-156.

13. Maksimaitis M. Kai kurios pirmųjų Lietuvos konstitucijų istoriografijos problemos. Jurisprudencija. 2002. Nr. 30(22). P. 182-190. 
14. Maksimaitis, M. Lietuvos teisès šaltiniai 1918-1940 metais : monografija. Vilnius : Justitia, 2001. 200 p.

15. Maksimaitis M. Lietuvos valstybès konstitucijų istorija: XX a. pirmoji pusė : monografija. Vilnius : Justitia, 2005. $392 \mathrm{p}$.

16. Maksimaitis M. Mažoji konstituanta: Lietuvos taryba atkuriant valstybingumą : monografija. Vilnius : Justitia, 2011. $431 \mathrm{p}$.

17. Сухомлинов В.А. Воспоминания. Берлин : Русское универсальное издательство, 1924. 438 с.

\section{References:}

1. Andriulis, V., et al. (2002). Lietuvos teisexs istorija [History of Lithuanian Law]. Vilnius: Justitia. 542 p. [in Lithuanian]

2. Averbah, O. (1915). Zakonodatel'nye akty, vyzvannye vojnoj 1914 goda s Germaniej, Avstro-Vengriej i Turciej [Legislation caused by the war of 1914 with Germany, Austria-Hungary and Turkey]. Vilnius: Tipografiya A. G. Syrpina. 686 p. [in Russian]

3. Berman, H. (1999). Teisex ir revoliucija. Vakaruu teisexs tradicijos formavimasis [Law and Revolution. The Formalion of the Western Legal Tradition] / vertex A. Sxliogeris. Vilnius: Pradai. 87 p. [in Lithuanian]

4. Grisxkevicx, L., Machovenko, J., Pauzxaitex-Kulvinskienex, J., Vaicxaitis, V. A. (2016). Lietuvos konstitucionalizmo istorija (istorinex Lietuvos konstitucija). 1387 m. - 1566 m. - 1791 m. - 1918 m. - 1990 m.: monografija [History of Lithuanian Constitutionalism (Historic Lithuanian Constitution) 1387, 1566, 1791, 1918, 1990: monograph]. Vilnius: Vilniaus universiteto leidykla. 280 p. [in Lithuanian]

5. Jusxkevicxiuxtex-Vilienex, A. (2017). Asmens uxkinexs veiklos laisvexs konstituciniai pagrindai Lietuvoje : ekonominexs, istorinexs ir lygynamosios iizxvalgos [Constitutional foundations of the freedom of individual economic activity in Lithuania : economic, historical and comparative insights]: daktaro disertacija, socialiniai mokslai, teisex (01 S). Vilnius: Vilniaus universitetas [in Lithuanian]

6. Lietuvos Valstybexs Laikinosios Konstitucijos Pamatiniai Dexsniai (1918). [Fundamental Laws of the Provisional Constitution of the State of Lithuania]. (Valstybexs tarybos priimta 1918 m. lapkricxio mexn. 2 d.). Lietuvos aidas, 130(178) [in Lithuanian]

7. Lietuvos Valstybexs Laikinosios Konstitucijos Pamatiniai Dexsniai (1919). [Fundamental Laws of the Provisional Constitution of the State of Lithuania]. Lietuvos valstybexs tarybos priimti 1919 m. balandzxio mexn. 4 d. Priedexlis prie Laikinosios vyriausybexs zxiniuu, $\mathrm{Nr}$. 6/24a [in Lithuanian]
8. Laikinoji Lietuvos Valstybexs Konstitucija (1920). [Provisional Constitution of the State of Lithuania]. Laikinosios Vyriausybexs zxinios, Nr. 37-407 [in Lithuanian]

9. Machovenko, E. (2019). Istoricheskaja Konstitucija Litvy kak chast' zapadnoj pravovoj tradicii i mesto v nej vremennoj Konstitucii 1919 goda [The historical Constitution of Lithuania as part of the Western legal tradition and the place in it of the provisional Constitution of 1919]. Konstytucijno-pravove budivnyctvo na zlami epoh: poshuky optymal'nyh modelej (m. Uzhgorod, 3-4 travnja 2019 r.). Uzhhorod: Uzhgorods'kyj nacional'nyj universytet, pp. 267-271 [in Ukrainian]

10. Machovenko, E. (2017). Konstitucionnye osnovy litovskogo chastnogo prava 1918-1920 gg [The constitutional foundations of the Lithuanian private law in 19181920]. Problemy grazhdanskogo prava i processa : sbornik nauchnyh statej. Grodno: Grodnenskij gosudarstvennyj universitet im. Janki Kupaly, pp. 199-211 [in Russian]

11. Machovenko, J. (2018). Teisexs viesxpatavimas $1918 \mathrm{~m}$. ir 1919 m. Lietuvos Valstybexs Laikinosios Konstitucijos Pamatiniuose Dexsniuose [The rule of law in the Fundamental Laws of the Temporary Constitution of the State of Lithuania of 1918 and 1919]. Local administration and Local self-government in the history of law, state and legal thought (Lviv, November 2-3, 2018). Kyiv-Kherson: Oldi-Plius, pp. 44-54. [in Lithuanian]

12. Machovenko, J., Valanciene D. (2018). Democracy in Lithuanian Temporary Constitutions of 1918 and 1919. Western and Eastern traditions and influences in the history of law, state and legal thought (Vinnytsia, June 1-3, 2018). Kyiv-Kherson: Oldi-Plius, pp. 143-156.

13. Maksimaitis, M. (2002). Kai kurios pirmuujuu Lietuvos konstitucijuu istoriografijos problemos [Some of the Problems in the Historiography of the First Constitutions of Lithuania]. Jurisprudencija, nr. 30(22), pp. 182190. [in Lithuanian]

14. Maksimaitis, M. (2001). Lietuvos teisexs sxaltiniai 1918-1940 metais: monografija [Law sources of Lithuania in 1918-1940: monograph]. Vilnius: Justitia. 200 p. [in Lithuanian]

15. Maksimaitis, M. (2005). Lietuvos valstybexs konstitucijuu istorija :XX a. pirmoji pusex: monografija [History of Lithuanian State Constitutions : the first half of the 20th century: monograph]. Vilnius: Justitia. 392 p. [in Lithuanian]

16. Maksimaitis, M. (2011). Mazxoji konstituanta : Lietuvos taryba atkuriant valstybingumaa: monografija [The Constituent Seimas : the Council of Lithuania in restoring statehood: monograph]. Vilnius: Justitia. 431 p. [in Lithuanian]

17. Suhomlinov, V. (1924). Vospominanija [Memories]. Berlin : Russkoe universal'noe izdatel'stvo. 438 p. [in Russian] 


\title{
КОНСТИТУЦІЙНІ ОСНОВИ КООРДИНАЦІЇ ПРИЙНЯТОГО ТА НАЦІОНАЛЬНОГО ПРАВА литвИ в 1918-1920 РР.
}

\author{
Євгеній Маховенко, \\ професор кафедри публічного права Вільнюського університету, \\ доктор сочіальних наук (право), професор \\ orcid.org/0000-0003-2930-3526 \\ jevgenij.machovenko@tf.vu.lt

\section{Довіле Валанчене} \\ асистент кафедри публічного права Вільнюського університету, \\ доктор соціальних наук (право), дощент \\ orcid.org/0000-0002-1034-1074 \\ dovile.valanciene@tf.vu.lt
}

\section{Анотація}

Об'єктом дослідження є положення Тимчасових конституцій 1918 року, 1919 і 1920 років, що стосуються створення правової системи Литви. Метою дослідження є визначення, що послужило підставою для сприйняття іноземного права і партикуляризму закону, який закон був прийнятий і який зв'язок між ним і новоствореним національним правом. Основними методами, які використовуються є: систематичний, телеологічний, історичний, лінгвістичний та порівняльний. У цій статті представлено оригінальне бачення прийнятого закону і критична оцінка міжвоєнного рішення уряду Литви повністю скасувати прийнятий закон. На думку авторів, сприйняття закону і партикуляризм, закріплені у Тимчасових конституціях, відповідали очікуванням громадян, а прагнення уряду повністю скасувати прийнятий закон у всіх сферах діяльності людей при інтенсивному розвитку національного права відповідало принципам стратегічних інтересів держави і суспільства. Партикуляризм був природним виразом плюралізму, властивого західній правовій традиції, і мав великий потенціал для розвитку литовського права, який не використовувався через негативну оцінку партикуляризму і спроб його повного усунення.

Акти, видані російською владою в 1914-1915 рр. та владою Німеччини в 1915-1918 рр., обмежували права жителів Литви, жорстко обмежували грошові та майнові відносини, ускладнювали відновлення економіки країни, передбачаючи репресивні або обмежувальні заходи проти громадяни ворожих держав. Відновлена Литовська держава прагнула встановити мирні відносини з усіма державами, включаючи ті, з якими Росія і Німеччина перебували у стані війни. Скасування закону, введеного владою Росії та Німеччини під час війни, було розумним і корисним рішенням влади Литви.

Поширене в історико-правовій літературі Литви тлумачення конституційної норми «[закони], що існували до війни» як «ті, що існували до 1 серпня 1914 року», неправильно. Питання про те, які закони були прийняті, повинно вирішуватися не за датою прийняття того чи іншого акту, а за його змістом - оскільки він пов'язаний або не має відношення до Першої світової війні. Всі дії, якими Російська імперія втручалася або готувалася втрутитися в ию війну, повинні вважатися виключеними з правової системи відновленої Литовської держави в сенсі конституційної норми «[закони], які існували до війни» і загальний дух цієї Конституції.

Система конституційного контролю, закріплена у Тимчасових конституціях, коли суд або виконавчий орган перевіряє відповідність прийнятого закону Конституції до його застосування, піддається критиці з точки зору сучасної юридичної науки, але в умовах Литви 1918-1920 рр., він був гнучким, швидким, дозволяючи громадянам піднімати питання про конституційність закону, представляючи свої аргументи.

Ключові слова: юридична історія; Тимчасові конституції Литви; прийняття закону; партикуляризм права; Західноєвропейська традиція права; правовий плюралізм; публічне право; приватне право. 